\title{
In the mood for wood-habitat specific colonization patterns of benthic invertebrate communities along the longitudinal gradient of an Austrian river
}

\author{
Florian Dossi 1 - Patrick Leitner $\cdot$ Steffen Pauls $\cdot$ Wolfram Graf
}

Received: 2 February 2017/Revised: 28 June 2017 / Accepted: 10 July 2017 / Published online: 24 July 2017

(C) The Author(s) 2017. This article is an open access publication

\begin{abstract}
Instream large wood (LW) constitutes an indispensable element of natural river ecosystems. It affects local hydraulics, morphology, nutrient budget, overall habitat complexity, and dynamics. Despite numerous studies about LW as a habitat for benthic communities, information on the varying importance along the longitudinal gradient of a river is lacking. The focus of this study is therefore to investigate general differences between lithal and xylal colonizers and to further investigate trends along the river course. We analyzed lithal and xylal communities at ten sites along the medium-sized Lafnitz River in Southeast Austria. Our results significantly show (1) a general differentiation between lithal and xylal communities, (2) an increasing distinction of the lithal and xylal
\end{abstract}

Electronic supplementary material The online version of this article (doi:10.1007/s10750-017-3307-z) contains supplementary material, which is available to authorized users.

Handling editor: Marcelo S. Moretti

F. Dossi $(\bowtie)$ - P. Leitner · W. Graf

IHG - Institute of Hydrobiology and Aquatic Ecosystem Management, BOKU - University of Natural Resources and Life Sciences, Gregor-Mendel-Strasse 33,

1180 Vienna, Austria

e-mail: florian.dossi@boku.ac.at

S. Pauls

Senckenberg Research Institute and Natural History

Museum Frankfurt, Senckenberganlage 25,

60325 Frankfurt am Main, Germany fauna along the longitudinal gradient of the river, and (3) a distinct correlation between the distance from source and the number of exclusive xylal and nowadays predominantly rare taxa. The presence of LW is therefore directly linked to higher aquatic biodiversity compared to rocky substrates and presents a unique element for river restoration, especially in lower river sections.

Keywords Community change .

Macroinvertebrates $\cdot$ River course $\cdot$ Xylal $\cdot$ Lafnitz

\section{Introduction}

Structural complexity, a key aspect in the maintenance of biodiversity and stability in ecosystems, is significantly affected by instream obstacles such as boulders and logs. Micro- and mesohabitat variety within a small spatial scale is a crucial factor for a selfsustaining and diverse riverine biocoenosis (Beisel et al., 1998, 2000). Like boulders and rocks, large wood (hereafter LW) and wood-accumulations have a strong influence on local hydraulics (e.g., Shields et al., 2001; Mutz, 2003; Manners et al., 2007; Blanckaert et al., 2014) and morphology (e.g., Gurnell et al., 1995; Keller et al., 1995; Kail, 2003; Blanckaert et al., 2014). Unlike rocks and boulders, LW also affects the nutrient budget of a river (e.g., Bilby, 1981; Hering \& Reich, 1997; Gurnell et al., 2005; Flores et al., 2011) and presents an important habitat structure 
that increases the density and diversity of fish and benthic invertebrate species in rivers and streams (e.g., Dudley \& Anderson, 1982; Copp, 1992; Hoffmann \& Hering, 2000; Pilotto et al., 2014, 2016). Partially submerged logs serve as important land-water interfaces and oviposition sites for merolimnic insects, thereby significantly affecting their reproductive success (Dudley \& Anderson, 1982; Sweeney, 1993; Hoffmann \& Hering, 2000).

The importance of LW has mainly been studied in North America (e.g., Anderson et al., 1978; Harmon et al., 1986; Maser \& Sedell, 1994; Abbe \& Montgomery, 1996; Bilby \& Bisson, 1998) as only few pristine river stretches with intact riparian vegetation and LW dynamics remain in Central Europe (Hering \& Reich, 1997; Hering et al., 2000; Tockner et al., 2009). Most studies focused on specific river sections. Information on the importance of LW for benthic invertebrate communities along the longitudinal gradient of a river is still lacking.

Lotic aquatic systems are characterized by continuous changes of physical and chemical variables, hydromorphological characteristics, and corresponding shifts of aquatic communities along the river course (Vannote et al., 1980; Cushing et al., 1983). Recent findings further show a varying availability and quality of wood habitats (e.g., total wood load, percentage of logs clustered in jams, the residence time of logs) along the longitudinal gradient of a river (Abbe \& Montgomery, 2003; Wohl \& Jaeger, 2009). The emphasis of wood and river interactions depends on the overall river characteristics such as the slope or $\log$ and river size ratio (Hering \& Reich, 1997; Scherle, 1999; Urbanek et al., 1999). In smaller rhithral river sections, LW primarily affects river morphology as it has the potential to significantly alter the surrounding habitat distribution or even the river course (Hering \& Reich, 1997; Urbanek et al., 1999; Kail, 2003). The concurrent presence of other coarse abiotic substrates in upper river stretches, which also provide stable habitats for benthic invertebrate species as well as attachment sites for periphytic algae, suggest only a negligible importance of LW as unique structure in upper river stretches. Effects on surrounding habitats and the retention of organic matter (debris dams) seem more profound. The presence and characteristics of LW significantly affects the food availability and composition (coarse vs. fine particulate matter) (Bilby \& Likens, 1980; Sedell \& Swanson,
1984; Speaker et al., 1984) which is known to be a key factor for the longitudinal distribution of species (Vannote et al., 1980). The function of LW as a unique and stable habitat becomes of greater importance in lower river parts commonly dominated by smaller grain sizes (Gurnell et al., 1995; Hering \& Reich, 1997) which is emphasized by the large number of potamal species documented as closely associated with wood (Hoffmann \& Hering, 2000). The absence of LW may therefore be a limiting factor, affecting overall biodiversity and population size of specific invertebrate species especially in lower courses.

We hypothesize a varying ecological function of LW as a habitat for benthic invertebrate species along the longitudinal gradient of the Lafnitz River. We expect similar lithal and xylal benthic communities in the upper river sections, while the communities should be distinctly different further downstream. Moreover, we predict benthic invertebrate density and biomass on LW will exceed those on lithal substrates along the entire river course. The central aims of this study are therefore (1) to investigate general differences in the lithal and xylal benthic community in terms of biodiversity and density and (2) to further evaluate the importance of LW as a habitat along the longitudinal gradient of the river based on exclusive and predominantly xylobiont species.

\section{Materials and methods}

Study sites

The study area covers the entire Austrian stretch of the Lafnitz River, one of the last medium-sized meandering rivers in Central Europe with near-natural hydromorphological dynamics, riparian vegetation, and LW depositions (single logs as well as larger LW accumulations, especially at its lower course) along large parts of its course. The Lafnitz lies within the Danube catchment, situated in the Southeast of Austria (Fig. 1) and drains into the Raab River after $112 \mathrm{~km}$, in Hungary. The catchment size at the Austrian border comprises approximately $2000 \mathrm{~km}^{2}$, making it the 13th largest river in Austria (BMLFUW, 2002; Cejka et al., 2005). The spring, located in Styria, originates at an altitude of $940 \mathrm{~m}$ a.s.l., the most downstream investigation site is located at $244 \mathrm{~m}$ a.s.l. Following Illies (1978), the first 36 river kilometers are situated 


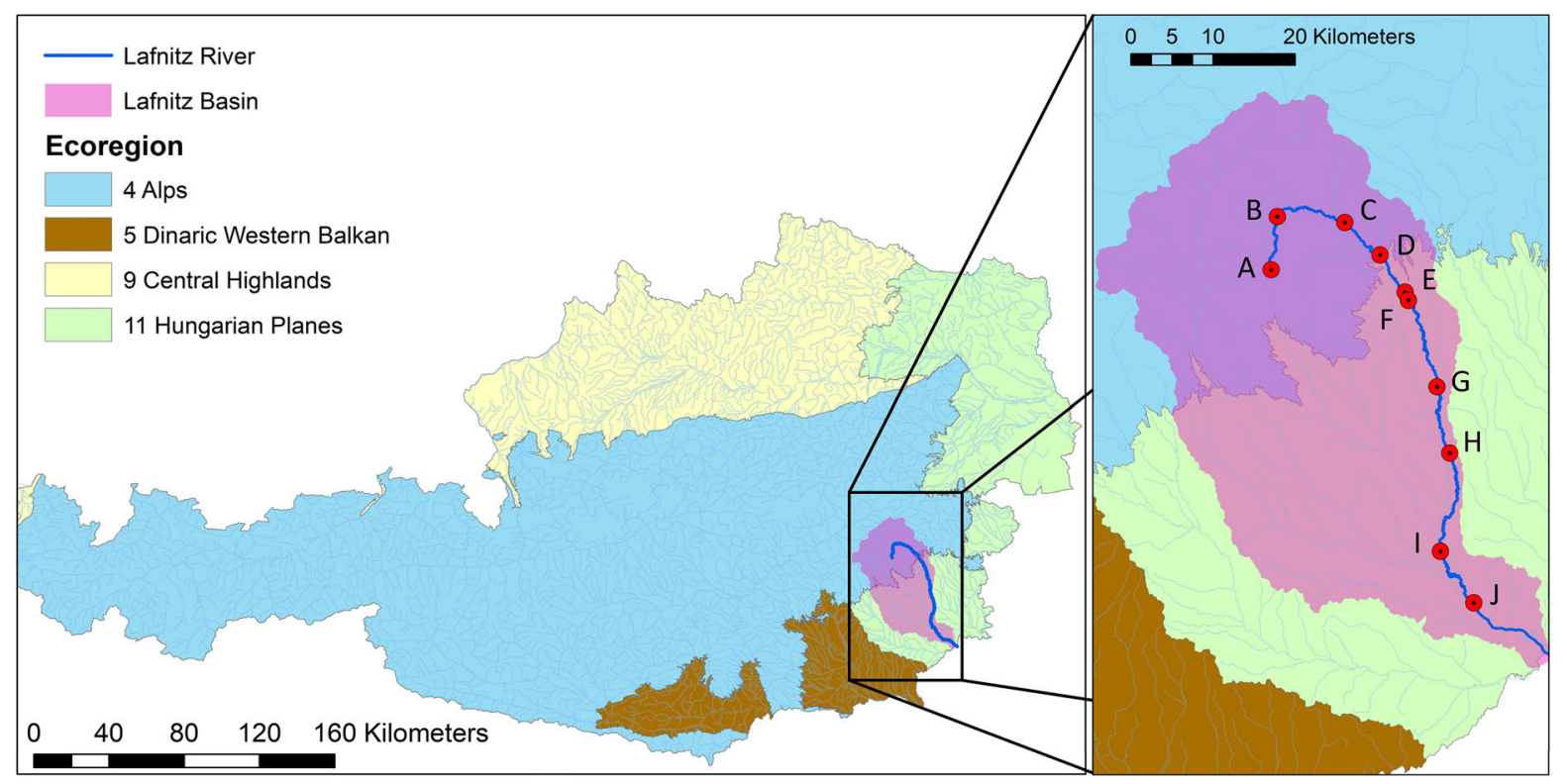

Fig. 1 Overview of the project area and location of the Lafnitz River in Austria (left) and location of the investigation sites along the river course (right); overlay: ecoregions according to Illies (1978)

in the ecoregion 4, "Alps", the middle to lower section in the ecoregion 11, "Hungarian Plains" (Fig. 1). The average discharge of the Lafnitz River in the lower section near the village Dobersdorf is about $6.3 \mathrm{~m}^{3} / \mathrm{s}$.

Ten study sites were investigated (Table 1 ). We tried to distribute the sampling sites at more or less even distances along the longitudinal gradient of the river. The exact sites were selected based on the stream order according to Strahler (1957) with additional consideration of major changes in the river slope, substrate composition, and river morphology. The locations of the sites are shown in Fig. 1. Site E and $\mathrm{F}$ are located much closer to each other compared to the other sites, as major morphological differences within a short river stretch were apparent (site $\mathrm{E}$ is located in a straightened river section; site $\mathrm{F}$ is located in an oxbows river section). Table 2 lists the site characteristics including the dominant grain size, whereby site $G$ showed an exceptional substrate composition. Although the dominant grain size at the

Table 1 Overview of site characteristics including altitude (meters above sea level), distance from spring $(\mathrm{km})$, mean river slope $(\%)$, dominant grain size $(\mathrm{cm})$, Strahler number (Strahler,

1957), average water depth (m), average flow velocity $(\mathrm{m} / \mathrm{s})$, and average river width $(\mathrm{m})$; asterisks $(*)$ highlights sites with large amounts of moving sands

\begin{tabular}{lllllllll}
\hline Site & $\begin{array}{l}\text { Altitude } \\
(\mathrm{m} \text { asl })\end{array}$ & $\begin{array}{l}\text { Distance from } \\
\text { Spring }(\mathrm{km})\end{array}$ & Slope $(\%)$ & $\begin{array}{l}\text { Dominant grain } \\
\text { size }(\mathrm{cm})\end{array}$ & $\begin{array}{l}\text { Strahler } \\
\text { number }\end{array}$ & $\begin{array}{l}\text { Average water } \\
\text { depth }(\mathrm{m})\end{array}$ & $\begin{array}{l}\text { Flow velocity } \\
(\mathrm{m} / \mathrm{s})\end{array}$ & $\begin{array}{l}\text { Average river } \\
\text { width }(\mathrm{m})\end{array}$ \\
\hline A & 933 & 0.3 & 9.5 & $6.3-40$ & 1 & 0.02 & 0.2 & 1 \\
B & 648 & 8.7 & 1.7 & $6.3-20$ & 4 & 0.2 & 0.3 & 8 \\
C & 524 & 19.3 & 1.2 & $6.3-20$ & 5 & 0.3 & 0.6 & 10 \\
D & 438 & 26.1 & 0.9 & $6.3-40$ & 5 & 0.3 & 0.6 & 15 \\
E & 410 & 32.4 & 0.4 & $2-6.3$ & 5 & 0.3 & 0.6 & 8 \\
F & 386 & 34.8 & 0.3 & $2-6.3$ & 5 & 0.5 & 0.4 & $15-20$ \\
G & 324 & 52.1 & 0.3 & $2-6.3 *$ & 5 & 0.5 & 0.3 & $10-20$ \\
H & 288 & 67.9 & 0.4 & $6.3-20$ & 5 & 0.5 & 0.45 & 12 \\
I & 480 & 87.0 & 0.1 & $6.3-20$ & 6 & 0.5 & 0.5 & 0.35 \\
J & 244 & 100.4 & $<0.1$ & $2-6.3$ & 6 & 0.6 & 0 \\
\hline
\end{tabular}


site was part of the micro-lithal fraction $(2-6.3 \mathrm{~cm})$ large parts of the river bed were covered with unstable sand layers, significantly altering the habitat quality at the site.

\section{Sampling and laboratory work}

Benthic sampling was performed in May and August 2012 at low flow conditions. Xylal and lithal substrates were sampled separately at each site. To support the identification of Trichoptera and Plecoptera species, additional samples were taken with light traps and sweeping nets on several dates from 2012 to 2014. Table 2 gives an overview of all samples taken.

Lithal-substrate sampling design was derived from the semi-quantitative multi-habitat-sampling-method (MHS) according to the AQEM Consortium (2002). A standardized $500 \mu \mathrm{m}$ mesh-size kick-net with a frame size of $25 \times 25 \mathrm{~cm}$ (surface area per single sample: $0.0625 \mathrm{~m}^{2}$ ) and a net length of $1.2 \mathrm{~m}$ was used as a sampling gear. Twenty pooled samples (corresponding to a $1.25 \mathrm{~m}^{2}$ surface area) were taken at each investigation site and date, whereby each single sample represents a 5\% share of available habitats in the river section. Only lithal habitats were sampled, regardless of the share of organic habitats present. This modified approach will further be referred to as lithalmulti-habitat-sampling (LMHS). In total, 19 LMHS

Table 2 Overview of samples taken in spring (left) and summer (right) of 2012; numbers indicate the total surface area $\left[\mathrm{m}^{2}\right]$ sampled at each site; asterisks $(*)$ highlight sites with sufficient samples available for comparative analyses (lithal/ xylal)

\begin{tabular}{llllll}
\hline Site & \multicolumn{2}{l}{$28-30$ May 2012} & & \multicolumn{2}{l}{$20-22$ August 2012} \\
\cline { 2 - 3 } \cline { 5 - 6 } \cline { 5 - 6 } & Lithal $\left(\mathrm{m}^{2}\right)$ & Xylal $\left(\mathrm{m}^{2}\right)$ & & Lithal $\left(\mathrm{m}^{2}\right)$ & Xylal $\left(\mathrm{m}^{2}\right)$ \\
\hline $\mathrm{A}$ & 1.25 & & 1.25 & \\
$\mathrm{~B}$ & 1.25 & & 1.25 & 0.76 \\
$\mathrm{C}$ & $1.25^{*}$ & $0.86^{*}$ & $1.25^{*}$ & $0.77^{*}$ \\
$\mathrm{D}$ & 1.25 & & 1.25 & \\
$\mathrm{E}$ & 1.25 & 0.77 & & \\
$\mathrm{~F}$ & $1.25^{*}$ & $1.18^{*}$ & $1.25^{*}$ & $0.7^{*}$ \\
$\mathrm{G}$ & $1.25^{*}$ & $1.31^{*}$ & $1.25^{*}$ & $1.26^{*}$ \\
$\mathrm{H}$ & $1.25^{*}$ & $1.74^{*}$ & $1.25^{*}$ & $0.71^{*}$ \\
$\mathrm{I}$ & $1.25^{*}$ & $0.93^{*}$ & $1.25^{*}$ & $0.91^{*}$ \\
$\mathrm{~J}$ & $1.25^{*}$ & $1.59^{*}$ & $1.25^{*}$ & $0.59^{*}$ \\
Total & $12.5 / 7.5^{*}$ & $8.38 / 7.61^{*}$ & $11.25 / 7.5$ & $5.7 / 4.94^{*}$ \\
\hline
\end{tabular}

samples, which correspond to a total riverbed surface area of $23.75 \mathrm{~m}^{2}$, were taken and analyzed (ten in May, nine in August of 2012; see Table 2).

LW sampling was also performed with the standardized kick-net (see above). At each site and date, a minimum of three logs from separate LW accumulations were sampled. Only decayed logs (decay classes 3-5 according to Robinson \& Beschta, 1990) with a minimum diameter of $5 \mathrm{~cm}$ and a minimum length of $80 \mathrm{~cm}$ were considered. All $\log$ s from each site were sampled in comparable flow and substrate conditions. If possible, whole logs were sampled. Due to the occurrence of large wood assemblages, especially at the sites $\mathrm{F}$ and $\mathrm{G}$ (Fig. 1), logs too long for sampling were cut off by using a handsaw. Prior to sampling, all logs were carefully surrounded with the kick-net to avoid organisms from drifting.

Benthic invertebrates were carefully brushed and washed from the logs into the kick-net. All organisms were preserved with formaldehyde (4\%). Length, width, and volume of each log was measured and the surface area was calculated using the formula of a simplified shape of a frustum of a cone:

$S=r^{2} \times \pi+\pi \times R^{2}+\pi \times s \times(r+R)$,

where $S=$ surface area, $r=$ radius $1, R=$ radius 2 , $s=$ slant height.

The surface area of the sampled logs varied between 0.4 and $1.15 \mathrm{~m}^{2}$. The volume of each $\log$ was measured using water expulsion in a tank and was primarily used to calibrate the calculated surface areas. The volume of the sampled logs varied between 1.5 and $9 \mathrm{dm}^{3}$. In total $42 \mathrm{LW}$ samples, which correspond to a total sampled wood surface area of $14.08 \mathrm{~m}^{2}$, were taken (21 in May, 21 in August of 2012; see Table 2).

As shown in Table 2, consistent LW sampling (three logs per site and date) was not possible at all ten sites. Sites where LW samples were inconsistent (sites A, B, D and E) were therefore excluded from all comparative analyses. Hence, a total of 12 LMHS and $36 \mathrm{LW}$ samples from six sites, which correspond to a lithal surface area of $15 \mathrm{~m}^{2}$ and a wood surface area of $12.55 \mathrm{~m}^{2}$, were available for comparative analyses. Longitudinal analyses were performed with presence/ absence transformed data from all samples and sites.

The Screening-Taxa List (Ofenböck et al., 2010) was used as a basis for identification. In many cases 
Ephemeroptera, Plecoptera, and Trichoptera taxa could be identified to a lower taxonomic level (genus/species), whereas Diptera taxa were mainly identified to family and Oligochaeta taxa only to order level. All taxa were counted and weighed (wet weight) to the lowest possible taxonomic level.

\section{Data analyses}

Statistical analyses were performed with the Software R-Studio 0.98.1091, IBM Statistics SPSS 21 and PCOrd 5.33.

The Levene's Test (Levene, 1960) was applied to ensure the equality of variances between lithal and xylal samples. All abundance and biomass data (lithal and xylal) were converted to square meter values (Ind/ $\mathrm{m}^{2} ; \mathrm{g} / \mathrm{m}^{2}$ ).

For cluster analyses the distance measure "relative Sørensen" ("relativized Manhattan" in Faith et al. (1987)) and the group-linkage method "Flexible Beta" (Lance \& Williams, 1967; $\beta=-0.15$ ) was used. Non-metric Multidimensional Scaling (NMDS; Kruskal, 1964) was performed using "Sørensen (Bray-Curtis)" as distance measure. Abundances for cluster and NMDS analyses were $\log (n+1)$ or presence/absence transformed. The Jaccard-Index (Jaccard, 1901) was used for similarity analyses of benthic communities of different sites or habitat types, respectively, and is calculated as:

$S_{j}=\frac{a}{(a+b+c)}$,

where $S_{j}=$ Jaccard-similarity coefficient, $a=$ number of taxa present in both habitats, $b=$ number of taxa present in habitat one, $c=$ number of taxa present in habitat two.

Longitudinal community analyses were performed on the basis of all taxa (including adult catches). Based on the taxonomic composition at each site, distinct segments were identified using a combination of cluster and similarity-analyses. Taxa referred to as "characteristic species" for specific segments are species which occurred nearly exclusively in one segment and have distinct distribution patterns along the longitudinal gradient of rivers according to Bauernfeind et al. (2002) and Graf et al. (2002a, b).

For comparative analyses (lithal/xylal) only benthic samples from sites with sufficient LW present at both sampling dates (see Table 2) were considered. The identification of taxa associated with wood was performed by combining three different approaches:

1. Identification of taxa exclusively present on wood.

2. Identification of taxa significantly overrepresented on wood using the index of representation (IR: Hildrew \& Townsend, 1976). The IR is calculated as:

$I R_{j}=\operatorname{stdd}_{\text {Res }} \cdot[j]=z_{j}=u_{j}=\frac{\left(O_{j}-E_{j}\right)}{\sqrt{E_{j}}}$,

$\sum E_{j}=\sum O_{j}$, where $j=1,2,3, \ldots(J-2)$, $(J-1), J=1[1] J)$, where $\mathrm{IR}_{j}=$ index of representation, $E=$ expected number of individuals of a given taxon in a single habitat, $O=$ observed number of individuals of a given taxon in a single habitat.

The IR, in a strict sense a test statistic, determines whether an observed frequency $(O)$ differs significantly from an (estimated) expected frequency (E) under the assumption of a particular theoretical distribution. Based on the theoretical level of significance a threshold of significance is determined. For a significance level of $\alpha=0.05$, as we used in our study, the threshold is $z=1.96$ (according to the standardized normal distribution). Interpretation for $\alpha=0.05$ :

- If $+z>+1.96$, a statistically significant "over-representation"/"preference" is given;

- If $-z<-1.96$, a statistically significant "under-representation"//aversion" is given;

- If $z$ lies within the interval (range) between -1.96 and +1.96 , neither significant undernor over- representation is given.

3. In addition, indicator species for each substrate type were defined with the indicator-speciesanalysis (ISA). All taxa with an Indicator value $(I V) \geq 25$ (Dufrene \& Legendre, 1997) and a $P$ value of $\alpha=0.05$ were considered as significant indicators.

This three-method approach was chosen as not all taxa which significantly benefit from the presence of wood are necessarily limited to wood as a habitat. Therefore, information regarding only the exclusive occurrence of taxa on wood is insufficient for a comprehensive view on wood associated taxa. 


\section{Results}

In total, 189 benthic invertebrate taxa were identified at ten investigation sites along the river course (see Table S1). All comparative analyses (lithal/xylal) are based on a total of 110 taxa from six sites (70 taxa in the lithal samples; 78 taxa in the xylal samples).

Lithal and xylal communities

Abundance and biomass did not show significant differences (Mann-Whitney Test; $\alpha=0.05$ ) between the substrate types. Only a minor trend towards lower abundance but higher biomass on xylal was noticeable (see Fig. S1). In addition, no significant biomass or abundance trends along the longitudinal gradient were obvious. Only a generally low biomass on both substrate types at the last two sites was evident (Fig. 2). Total taxa number was slightly higher or equal on xylal at all sites, except at site $\mathrm{C}$. The most considerable differences were found at site $\mathrm{G}$, with 28 taxa in the lithal samples compared to 52 taxa in the xylal samples (Fig. 2).

In contrast, distinct differences were evident regarding the taxonomic composition. The NMDSscatterplot shows a clear separation between the xylal and lithal fauna with an increasing distinction along the longitudinal gradient of the river. Moreover, a distinct succession of both, lithal and xylal communities, along the river course is clearly visible (Fig. 3). The Jaccard-coefficient between both communities decreased from 0.57 in the upper to 0.39 in the lower river stretch and further shows a clear correlation with the distance from source (Fig. $4 ; R^{2}$ linear $=0.88$ ). This illustrates that xylal and lithal communities were more similar in upstream sections compared to downstream sites. Yet, the overall comparison of xylal and lithal samples, regardless of the sampling site, showed a greater similarity (Jaccard-coefficient of 0.66; Fig. 4, right).

A remarkable contrast between lithal and xylal communities was observed at site G. Even though the Jaccard-coefficient showed no exceptional values compared to the adjacent sites, the highest difference in taxa richness between the substrate types (lithal 28 taxa; xylal 52 taxa) as well as the lowest benthic invertebrate densities $\left(1076 \mathrm{Ind} / \mathrm{m}^{2}\right)$ on lithal among all investigation sites was found there (Fig. 2). The nonetheless high value of the Jaccard-coefficient can be explained by a high faunistical overlap as all taxa found in the lithal samples (except Leuctra sp. and Hexatoma sp.) were also present in the xylal samples.

Longitudinal community analyses

The combined results from cluster- and similarityanalyses revealed four distinctly separated benthic communities along the river course (Fig. 5, right). The fauna at site A formed a distinctive community as numerous spring-associated species of Trichoptera (e.g., Apatania fimbriata (Pictet, 1834), Drusus annulatus (Stephens, 1837), Rhyacophila hirticornis Mclachlan, 1879; and Plecoptera [e.g., Isoperla tripartita Illies, 1954 and Siphonoperla neglecta (Rostock \& Kolbe, 1888)] were exclusively found there. The first site was therefore categorized as one separate unit. The low Jaccard-similarity of $33.5 \%$ between the sites $\mathrm{A}$ and $\mathrm{B}$ underlined its unique taxa composition.

A second community was evident between the sites $\mathrm{B}$ and E. The species composition barely changed between the first three sites, shown by high Jaccard-
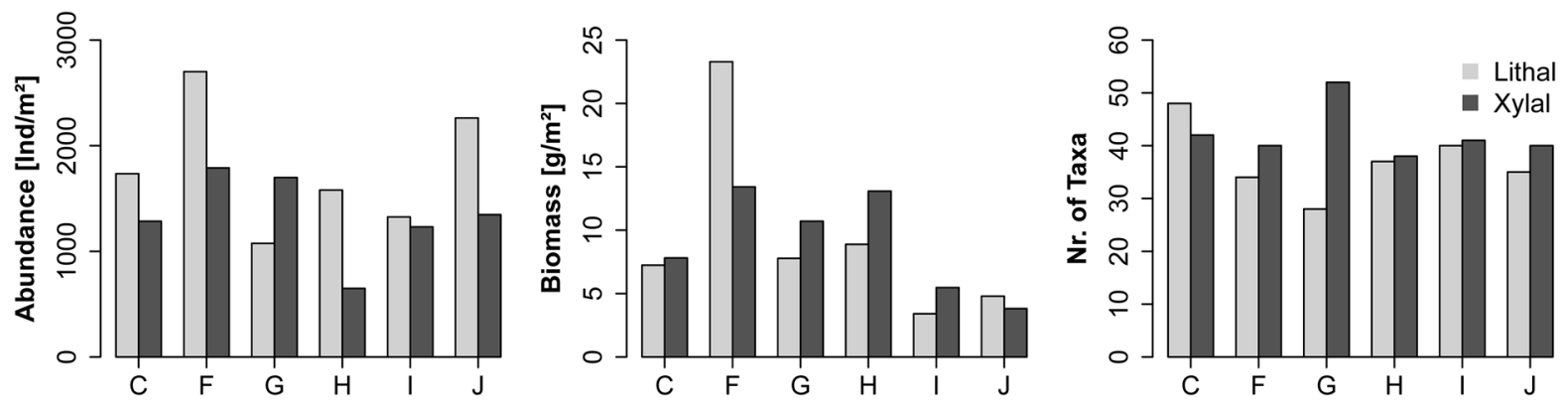

Fig. 2 Longitudinal comparison of the mean abundance (Individuals $\left./ \mathrm{m}^{2}\right)(l e f t)$, mean biomass $\left(\mathrm{g} / \mathrm{m}^{2}\right)$ (middle), and total number of taxa (right) at each site between lithal (light grey) and xylal (dark grey) at the sites C, F, G, H, I, and J 


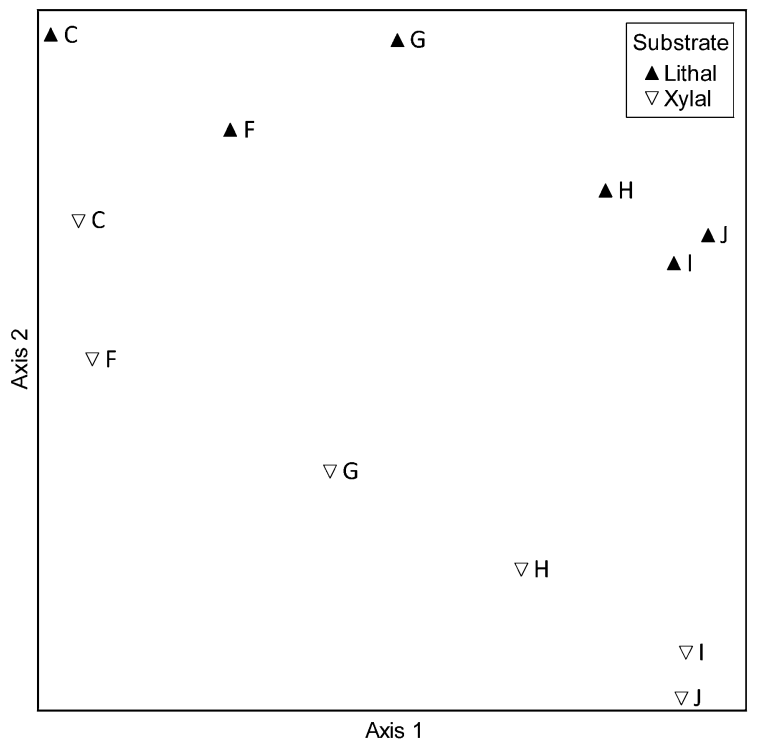

Fig. 3 Scatterplot of the NMDS analysis for lithal (black) and xylal (white) samples based on the species composition at the sites C, F, G, H, I, and J; stress: 9.83 for 2-dimensional solution (number of iterations $=48$ )

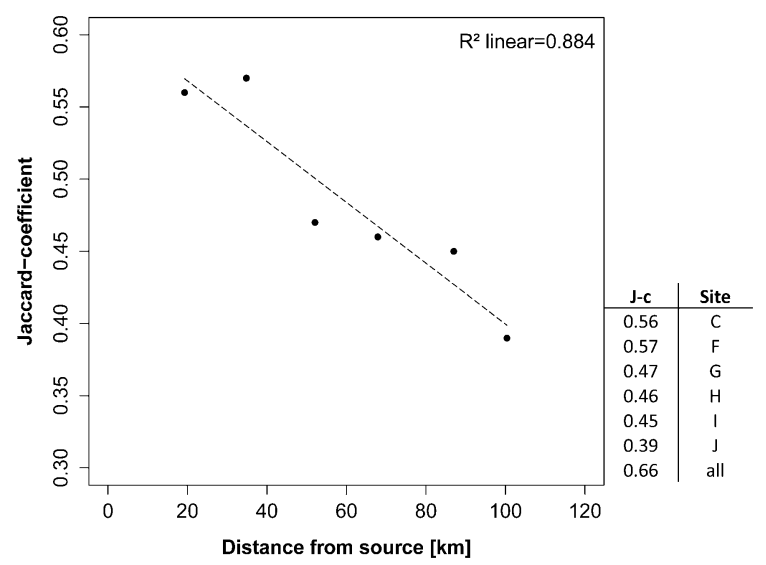

Fig. 4 Correlation of the Jaccard-coefficient comparing lithal and xylal species communities at each site and the distance from source (left) $\left(R^{2}=0.884\right)$; Table summarizing the Jaccardcoefficients $(J-c)$ from each site and the $J-c$ of the pooled lithal and xylal samples (all)

similarities and lower distances in the cluster dendrogram (Fig. 5). Characteristic species found were as follows: Baetis alpinus (Pictet, 1843-1845), Rhithrogena picteti (Sowa, 1971), Allogamus auricollis (Pictet, 1834), Ecclisopteryx madida (Mclachlan, 1867) and Rhyacophila tristis (Pictet, 1834). Site E, although part of the segment, showed an exceptional faunal composition. Taxa typical for both rithral and hyporhithral reaches of the river were present at this site. However, cluster and similarity analyses suggest the integration into the second segment, because rhithral taxa were more dominant.

The faunal composition of the adjacent sites F-I, categorized as the third segment, represented a characteristic hyporhithral to epipotamal community, e.g., Trichoptera: Hydropsyche siltalai (Döhler, 1963), Lepidostoma basale, Polycentropus flavomaculatus (Pictet, 1834); Plecoptera: Brachyptera braueri (Klapalek, 1900), Isoperla grammatica (Poda, 1761); Ephemeroptera: Baetis fuscatus (Linnaeus, 1761), Heptagenia flava (Rostock, 1877), Heptagenia longicauda (Stephens, 1836).

Due to the presence of numerous exclusive taxa, e.g., Ephemeroptera: Ametropus fragilis (Albarda, 1878); Plecoptera: Agnetina elegantula (Klapalek, 1905), Besdolus ventralis (Pictet, 1841), Taeniopteryx nebulosa (Linnaeus, 1758); Trichoptera: Hydroptila simulans (Mosely, 1920), Hydroptila sparsa (Curtis, 1834), Stactobiella risi (Felber, 1908), Ylodes simulans (Tjeder, 1929) the most downstream site J was classified as a discrete community.

Taxa associated with wood

Ten taxa were exclusively present in the xylal samples. The number of exclusive taxa per site shows a significant correlation (Pearson Correlation: $\alpha=0.01$; two-tailed; $r=0.929$ ) with the distance from source (Fig. 6). All following results are summarized in Table 3.

The largest share of exclusive xylal taxa was found within the group of Trichoptera [Anabolia furcata (Brauer, 1857), Lype phaeopa (Stephens, 1936) and Lepidostoma hirtum (Fabricius, 1775)]. In addition, two Ephemeroptera species [H. longicauda and Paraleptophlebia submarginata (Stephens, 1835)], two Odonata species [Calopteryx virgo (Linnaeus, 1758), Gomphus vulgatissimus (Linnaeus, 1758)], two Coleoptera taxa (Dryops sp., Macronychus quadrituberculatus (Müller, 1806)) and one Plecoptera species (A. elegantula) were exclusively found on xylal. Besides the two Ephemeroptera (H. longicauda and $P$. submarginata) and one Trichoptera species ( $L$. phaeopa) all other mentioned taxa were exclusively present at the last sites I and J.

The Index of Representation $(\alpha=0.05)$ classified 16 additional taxa as significantly overrepresented on 


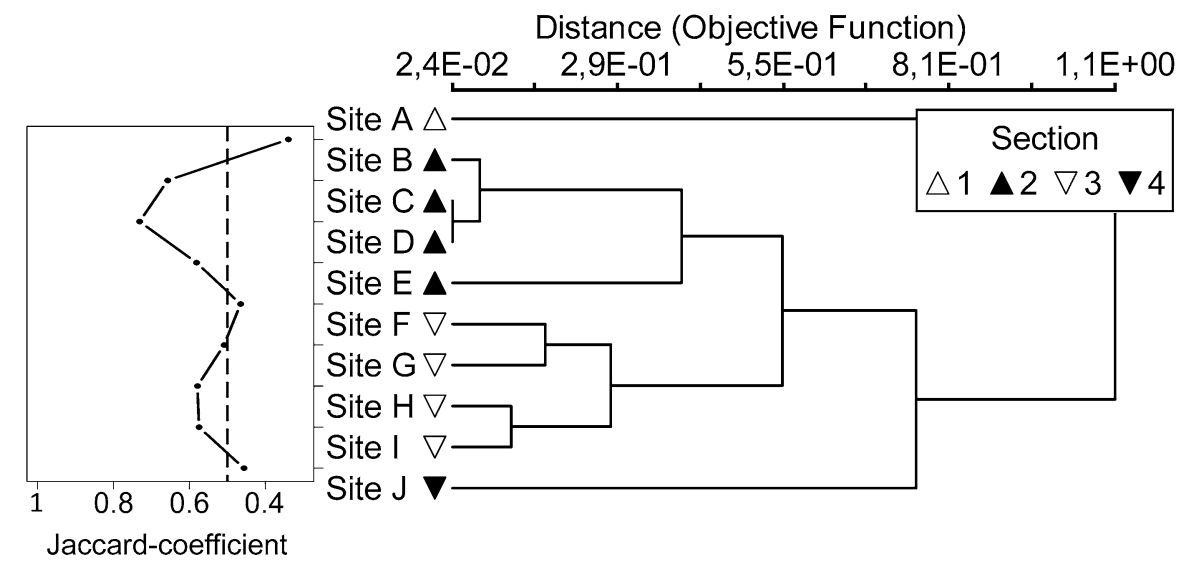

Fig. 5 Jaccard-coefficient based on the species composition of sequent sites (dashed line highlights Jaccard-coefficient of 0.5) (left); cluster analysis (distance measure: Soerensen; grouplinkage-method: Flexible Beta $=-0.15$ ) based on the species

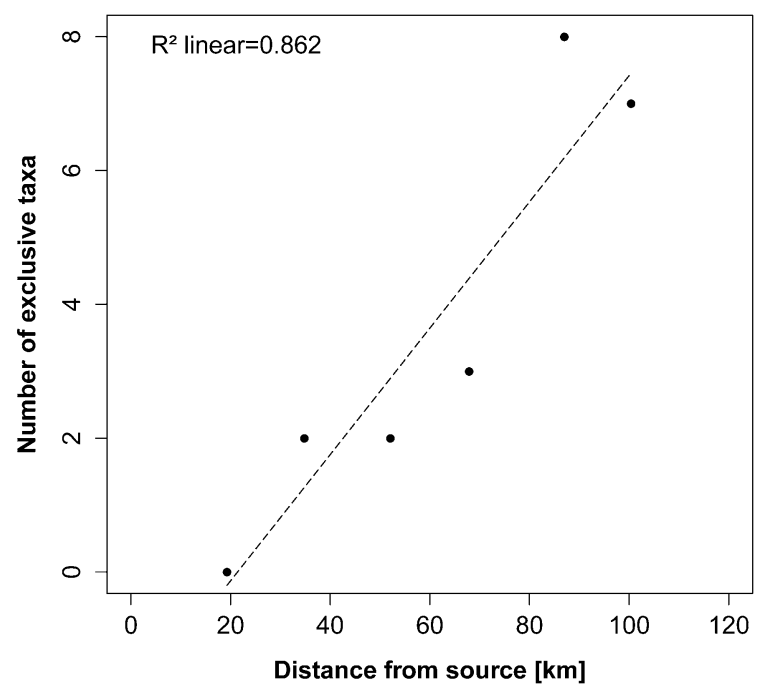

Fig. 6 Correlation of the number of taxa exclusively found on xylal at each site (sites C, F, G, H, I, and J) and the distance from source $\left(R^{2}=0.862\right)$

wood, mainly among Trichoptera (e.g., Halesus sp., Hydropsyche instabilis (Curtis, 1834), L. basale, Potamophylax rotundipennis (Brauer, 1857), R. tristis), and Plecoptera (Amphinemura sp, Isoperla sp., Protonemura sp.). Moreover, two Coleoptera (Elmis sp. (Latreille, 1802), Orectochilus villosus (Müller, 1776)), two Ephemeroptera (Ephemerella ignita (Poda, 1761), H. flava) and one Crustacea taxon (Gammarus fossarum (Koch, 1835)) showed significantly higher abundances on LW. The IndicatorSpecies-Analysis (IV $\geq 25 ; \alpha=0.05$ ) identified nine composition of each site (right), all samples (LW, lithal and light traps/sweeping net) from both seasons included; all data were presence-absence transformed

taxa as significant indicators for wood: Three Coleoptera taxa (Elmis sp., M. quadrituberculatus, O. villosus), two Ephemeroptera species (H. flava, $H$. longicauda), two Plecoptera taxa (A. elegantula, Isoperla sp.), one Trichoptera taxon (Halesus sp.), and the Crustacea species G. fossarum (see Table 3).

In addition, the frequency of occurrence of all taxa classified as associated with LW was calculated (Table 3: \%LW(all)). Nine out of 29 taxa defined as associated with wood were present in more than $50 \%$ of all xylal samples. Most of the taxa were frequently found within one river section (Table 3: \% LW(S2S4)). Only Elmis sp. and G. fossarum were present in all xylal samples along the whole river course. Furthermore, Table 3 shows that the majority of significant indicators for wood according to the ISA have their main distribution area within the last river section (S4).

\section{Discussion}

Results from previous studies comparing lithal and xylal habitats varied greatly, but predominantly showed higher benthic invertebrate density and diversity on LW compared to adjacent lithal habitats (e.g., Benke et al., 1984; Wallace \& Benke, 1984; Smock et al., 1985, 1989, 1992; O'Connor, 1992; Hoffmann \& Hering, 2000; Benke \& Wallace, 2003; Milner \& Gloyne-Phillips, 2005; Coe et al., 2009). Contrary to our assumptions, these findings were not confirmed by 
Table 3 Overview of taxa exclusively (bold) and significantly more abundant on wood: $\% L W($ all $)$ indicates the percentage of xylal samples in which the taxon was found; \% $L W(S 2 / S 3 / S 4)$ indicates the percentage of xylal samples in which the taxon

\begin{tabular}{|c|c|c|c|c|c|c|}
\hline Order & Taxon & $\%$ LW (all) & $\% \mathrm{LW}(\mathrm{S} 2)$ & \%LW (S3) & $\% \mathrm{LW}(\mathrm{S} 4)$ & IV \\
\hline \multirow[t]{4}{*}{ Coleoptera } & Dryops sp. & 17 & 0 & 13 & 50 & 16.7 \\
\hline & Elmis sp. & 100 & 100 & 100 & 100 & $85.6^{* *}$ \\
\hline & Macronychus quadrituberculatus & 33 & 0 & 25 & 100 & $58.3 * *$ \\
\hline & Orectochilus villosus & 58 & 0 & 75 & 100 & $58.3 * *$ \\
\hline Crustacea & Gammarus fossarum & 100 & 100 & 100 & 100 & $80.8^{*}$ \\
\hline \multirow[t]{4}{*}{ Ephemeroptera } & Ephemerella ignita & 92 & 50 & 100 & 100 & 73.9 \\
\hline & Heptagenia flava & 75 & 0 & 88 & 100 & $72.7 * *$ \\
\hline & Heptagenia longicauda & 75 & 0 & 88 & 100 & $75^{* *}$ \\
\hline & Paraleptophlebia submarginata & 8 & 0 & 13 & 0 & 8.3 \\
\hline \multirow[t]{2}{*}{ Odonata } & Calopteryx virgo & 8 & 0 & 0 & 50 & 8.3 \\
\hline & Gomphus vulgatissimus & 17 & 0 & 13 & 50 & 16.7 \\
\hline \multirow[t]{4}{*}{ Plecoptera } & Agnetina elegantula & 25 & 0 & 13 & 100 & $25^{*}$ \\
\hline & Amphinemura sp. & 33 & 50 & 38 & 0 & 31.8 \\
\hline & Isoperla sp. & 58 & 100 & 63 & 0 & $54 *$ \\
\hline & Protonemura sp. & 17 & 100 & 0 & 0 & 16.4 \\
\hline \multirow[t]{11}{*}{ Trichoptera } & Allogamus auricollis & 25 & 100 & 13 & 0 & 21.8 \\
\hline & Anabolia furcata & 17 & 0 & 13 & 50 & 16.7 \\
\hline & Chaetopteryx fusca & 25 & 0 & 38 & 0 & 23.5 \\
\hline & Halesus sp. & 67 & 50 & 75 & 100 & $64.5^{* *}$ \\
\hline & Hydropsyche instabilis & 33 & 50 & 38 & 0 & 30.4 \\
\hline & Lepidostoma basale & 50 & 50 & 50 & 50 & 43.8 \\
\hline & Lepidostoma hirtum & 8 & 0 & 13 & 0 & 8.3 \\
\hline & Lype phaeopa & 33 & 0 & 50 & 0 & 33.3 \\
\hline & Potamophylax rotundipennis & 33 & 50 & 38 & 0 & 33.3 \\
\hline & Rhyacophila s.str.sp. & 58 & 100 & 63 & 0 & 42.5 \\
\hline & Rhyacophila tristis & 25 & 100 & 13 & 0 & 24.9 \\
\hline
\end{tabular}

was found in the respective river segments $2 / 3 / 4$ (see Fig. 6); $I V$ indicator value; $P$ level of significance of the indicator value (*0.05;**0.01) our study. Comparison of all lithal and xylal samples, regardless of the investigation site, showed no significant differences in taxa richness, density or biomass.

One main reason for these results is due to the approach of our study. Previous works, predominantly focusing on particular river sections, observed the most considerable density and biomass differences amongst lithal and xylal habitats at sites with a high share of fine and/or unstable sediments (Benke et al., 1984; Wallace \& Benke, 1984; Smock et al., 1985, 1989, 1992; Hoffmann \& Hering, 2000). Coarser sediments, however, dominate the majority of the investigated river stretch. Only site $\mathrm{G}$ showed comparable substrate conditions and corresponding results to the above-mentioned studies. Even though the overall species composition and density (lithal and xylal combined) showed no considerable differences to adjacent sites, siltation lead to major colonization disparities amongst the substrate types (Graf et al., 2016a). Benthic invertebrate density and diversity on xylal was approximately twice as high compared to surrounding sand habitats. Thus, about one half of all taxa were exclusively present in the LW samples. Conversely, nearly all taxa present in the lithal samples occurred in the xylal samples too. These observations are consistent with literature (Connoly \& Pearson, 2007; Extence et al., 2011). Siltation generally leads to an alteration of the habitat distribution and quality (Wood \& Armitage, 1997; Kaller \& Hartmann, 2004), which prevents the establishment of 
a distinct lithal community. Often LW is suspended in the current and is thus more resilient to siltation, and therefore remains as a unique stable structure and represents an important refuge habitat (Smock et al., 1989; Gurnell et al., 1995; Hering \& Reich, 1997).

Based on the benthic invertebrate community structure, our data revealed an increasing importance of LW as a habitat for benthic invertebrates along the longitudinal gradient of the Lafnitz River. Within the investigated river stretch, four distinct benthic communities were identified, with only those in the lower river parts considerably benefitting from LW as a habitat.

LW only had a negligible influence on the species composition in the upstream river section at Site C. Even though no wood was present at adjacent sites (Site B and Site D), no significant differences in the overall species composition between the Sites B, C and $\mathrm{D}$ were evident. Detailed taxonomical analyses showed that differences between LW and lithal habitats at site $\mathrm{C}$ were mainly caused by taxa exclusively present in the lithal samples. Further differences seem to be mainly induced by the altered hydraulic situation as LW structures provide lentic habitats in fast flowing rhithral sections (Diez et al., 2000; Gurnell et al., 2005). Correspondingly, taxa missing in the xylal samples were mainly rheobiont such as Rhithrogena spp., Rhyacophila torrentium (Pictet, 1834), Ancylus fluviatilis (O.F. Müller, 1774), and Blephariceridae species (Buffagni et al., 2016; Graf et al., 2016b; Schmidt-Kloiber \& Hering, 2016). Conversely, current-sensitive, lentic taxa, e.g., A. auricollis, Halesus sp., and Potamophylax spp. (Graf et al., 2016b) were significantly more abundant in the xylal samples.

The most considerable taxonomic differences were evident in the lower river segments. In total 10 exclusive xylal taxa were identified. These taxa were exclusively found in the last two river segments. Moreover, a distinct correlation with the number of exclusive taxa and the distance from source was evident. For numerous species instream wood presents an indispensable habitat within certain life stages or affects the reproductive success, but their occurrence is not necessarily limited to wood (Pareira et al., 1982; Sweeney, 1993; Hoffmann \& Hering, 2000). Accordingly, taxa significantly more abundant on LW were identified, resulting in a total of 29 taxa classified as associated with wood at the Lafnitz River. Only half of these taxa have already been referred to as associated with wood (Hoffmann \& Hering, 2000; Buffagni et al., 2016). The large number of exclusive xylal taxa recorded impressively shows the importance of LW as a unique and irreplaceable habitat in lower river parts. The presence of LW is therefore directly linked with a considerable increase in aquatic biodiversity.

Common characteristics of the taxa associated with wood seem to be related to their feeding ecology. Besides xylophagous taxa (e.g., Coleoptera: $M$. quadrituberculatus, Trichoptera: L. phaeopa, $L$. basale) the vast majority is classified as functional feeding type shredders (e.g., G. fossarum, $P$. rotundipennis), grazers (e.g., Coleoptera: Elmis sp.; Ephemeroptera: E. ignita, H. flava), and predators (e.g., Odonata: G. vulgatissimus, Plecoptera: $A$. elegantula), which are known to benefit from various effects of LW (Hoffmann \& Hering, 2000; Buffagni et al., 2016; Graf et al., 2016b). The provision of lentic habitats and the accumulation of organic matter by LW (Bilby \& Likens, 1980; Sedell \& Swanson, 1984; Speaker et al., 1984) promotes shredder and predator densities (Laasonen et al., 1998; Benke \& Wallace, 2003; Miller et al., 2010). Additionally, the development of a highly productive epixylic biofilm on wood and other coarse organic matter (Golladay \& Sinsabaugh, 1991; Sinsabaugh et al., 1991) presents an attractive food source for grazing taxa.

Major human impacts on riparian vegetation, restraining LW recruitment, and the additional active removal of instream wood in the past decades lead to a massive habitat loss of xylobiont biota especially in the lower river course (Hering et al., 2000; Elosegi \& Johnson, 2003; Hohensinner et al., 2016). Therefore, numerous xylobiont taxa present in the Lafnitz River, e.g., M. quadrituberculatus, H. longicauda, and A. elegantula are nowadays threatened or rare species (Graf, 1997; Bauernfeind \& Humpesch, 2001; Graf \& Kovacs, 2002; Jäch et al., 2005; Buffagni et al., 2016), emphasizing the unique importance of LW structures as a habitat, particularly in downstream reaches where stable structures are otherwise lacking. In the case of the stonefly $A$. elegantula the Raab/Lafnitz river catchment is the last known distribution area in Central Europe (Graf, 1997; Graf \& Kovacs, 2002). Additionally, the irregular occurrence of most xylobiont species, even within the river segments, indicates that not only the presence of submerged LW is of importance. As previous studies already suggested, the 
state of decay, texture, and species of wood seem to be important factors influencing the interaction of wood and aquatic biota (Anderson et al., 1978; Dudley \& Anderson, 1982; Kaufman \& King, 1987; Magoulick, 1998; Hofer \& Richardson, 2007) and should be accounted in future studies. Considering the significant influence of LW on hydromorphology, river dynamics, and habitat diversity (Gurnell et al., 1995; Gerhard \& Reich, 2000; Kail et al., 2007) as well as the importance as unique habitat emphasizes the importance of LW as important element of natural rivers and a valuable asset in the process of river restoration and revitalization.

\section{Conclusion}

The results of this study emphasize the importance of LW as a habitat for riverine ecosystems. The presence of wood, especially in potamal river sections, is linked with a considerable increase of aquatic biodiversity. While in the upper reach the majority of taxa colonized both substrate types equally (lithal and xylal habitats respectively), the number of taxa living exclusively on LW increased steadily along the river course. Out of ten taxa exclusively present on wood, only one was documented in the upper river parts. Furthermore, the exclusive occurrence of numerous taxa on wood highlights its unique and irreplaceable status as habitat structure. Major human impacts on riparian vegetation and the long history of instream wood removal lead to a massive habitat loss of xylobiont species, which is underlined by the occurrence of numerous threatened or rare species (e.g., $A$. elegantula and $M$. quadrituberculatus) (Graf \& Kovacs, 2002; Jäch et al., 2005) on LW at the Lafnitz River.

Acknowledgements Open access funding provided by University of Natural Resources and Life Sciences Vienna (BOKU). We would like to thank all members of the working group "Benthic Ecology and Ecological Status Assessment" at the Institute of Hydrobiology and Aquatic Ecosystem Management for constant support. We are especially thankful to Lisa Schülting and Mary-Anne Chesley for countless valuable comments on the manuscript as well as to Thomas Huber and Eva Steindl for the support during the identification work. This study was part of the Bio-Clic project financed by the Austrian Climate and Energy Fund (Grant No. ACRP B175079).
Open Access This article is distributed under the terms of the Creative Commons Attribution 4.0 International License (http:// creativecommons.org/licenses/by/4.0/), which permits unrestricted use, distribution, and reproduction in any medium, provided you give appropriate credit to the original author(s) and the source, provide a link to the Creative Commons license, and indicate if changes were made.

\section{Reference}

Abbe, T. \& D. Montgomery, 1996. Large woody debris jams, channel hydraulics and habitat formation in large rivers. Regulated Rivers Research \& Management 12: 201-221.

Abbe, T. \& D. Montgomery, 2003. Patterns and processes of wood debris accumulation in the Queets river basin, Washington. Geomorphology 51: 81-107.

Anderson, N., J. Sedell, L. Roberts \& F. Triska, 1978. The role of aquatic invertebrates in processing of wood debris in coniferous forest streams. The American Midland Naturalist 100: 64-82.

AQEM Consortium, 2002. Manual for the Application of the AQEM System. A Comprehensive Method to Assess European Streams using benthic macroinvertebrates, developed for the purpose of the Water Framework Directive. Report, financed by European Union, 5th Framework Programme.

Bauernfeind, E. \& U. Humpesch, 2001. Die Eintagsfliegen Zentraleuropas (Insecta: Ephemeroptera): Bestimmung und Ökologie. Monografien Entomologie Gemischt 26: 1-239.

Bauernfeind, E., O. Moog \& P. Weichselbaumer, 2002. Ephemeroptera- Teil III. In Moog, O. (ed), Fauna Aquatica Austriaca, Lieferung 2002. Wasserwirtschaftskataster, Bundesministerium für Land- und Forstwirtschaft, Umwelt und Wasserwirtschaft, Wien.

Beisel, J. N., P. Usseglio-Polatera, S. Thomas \& J. C. Moreteau, 1998. Stream community structure in relation to spatial variation: the influence of mesohabitat characteristics. Hydrobiologia 389: 73-88.

Beisel, J. N., P. Usseglio-Polatera \& J. C. Moreteau, 2000. The spatial heterogeneity of a river bottom: a key factor determining macroinvertebrate communities. Hydrobiologia 422: 163-171.

Benke, A. \& B. Wallace, 2003. Influence of wood on invertebrate communities in streams and rivers wood-created habitat. American Fisheries Society Symposium 37: 149-177.

Benke, A., T. Van Arsdall, D. Gillespie \& F. Parish, 1984. Invertebrate productivity in a subtropical blackwater river: the importance of habitat and life history. Ecological Monographs 54: 25-63.

Bilby, R., 1981. Role of organic debris dams in regulating the export of dissolved and particulate matter from forested watershed. Ecology 62: 1234-1243.

Bilby, R. \& P. Bisson, 1998. Function and distribution of large woody debris. In Naiman, R. \& G. Likens (eds), River Ecology and Management. Springer, New York: 324-346. 
Bilby, R. \& G. Likens, 1980. Importance of organic debris dams in the structure and function of stream ecosystems. Ecology 51: 1107-1113.

Blanckaert, K., R. Han, F. Pilotto \& M. Pusch, 2014. Effects of large wood on morphology, flow and turbulence in a lowland river. In Schleiss, A. J., G. de Cesare, M. J. Franca \& M. Pfister (eds), River Flow 2014. CRC Press, Boca Raton: 2493-2501.

BMLFUW-Bundesministeriums für Land- und Forstwirtschaft, Umwelt und Wasserwirtschaft, 2002. Gewässerschutzbericht 2002. BMLFUW, Wien.

Buffagni, A., D. G. Armanini, M. Cazzola, J. Alba-Tercedor, M. J. López-Rodríguez, J. Murphy, L. Sandin \& A. SchmidtKloiber, 2016. Dataset "Ephemeroptera". www. freshwaterecology.info-the taxa and autecology database for freshwater organisms, version 6.0 (accessed on 18.04.2016).

Cejka, A., M. Dvorak, I. Fortmann, E. Knogler, I. Korner, G. Schlögl, B. Wendelin, G. Wolfram \& T. C. Zechmeister, 2005. Das Lafnitztal. Flusslandschaft im Herzen Europas. Neuer Wissenschaftlicher Verlag, Wien: 1-233.

Coe, H., P. Kiffney, G. Pess, K. Kloehn \& M. McHenry, 2009. Periphyton and invertebrate response to wood placement in large pacific coastal rivers. River Research and Applications 25: 1025-1035.

Connoly, N. M. \& R. G. Pearson, 2007. The effect of fine sedimentation on tropical stream macroinvertebrate assemblages: a comparison using flow-through artificial stream channels and recirculating mesocosms. Hydrobiologia 592: 423-438.

Copp, G., 1992. Comparative microhabitat use of cyprinid larvae and juveniles in a lotic floodplain channel. Environmental Biology of Fishes 33: 181-193.

Cushing, C., C. McIntire, K. Cummins, G. Minsahall, R. Petersen \& J. Sedell, 1983. Relationship among physical, chemical and biological indices along river continua based on multivariate analyses. Archiv für Hydrobiologie 98: 317-326.

Diez, J., S. Larranaga, A. Elosegi \& J. Pozo, 2000. Effect of removal of woody debris on streambed stability and retention of organic matter. Journal of the North American Benthological Society 19: 621-632.

Dudley, T. \& N. Anderson, 1982. A survey of invertebrates associated with wood debris in aquatic habitats. Melanderia 39: 1-21.

Dufrene, M. \& P. Legendre, 1997. Species assemblages and indicator species: the need for a flexible asymmetrical approach. Ecological Monographs 67: 345-366.

Elosegi, A. \& L. B. Johnson, 2003. Wood in streams and rivers in developed landscapes. In Gregory, S., K. Boyer \& A. Gurnell (eds), The ecology and management of wood in world rivers. American Fisheries Society, Bethesda: 337-353.

Extence, C. A., R. P. Chadd, J. England, M. J. Dunbar, P. J. Wood \& E. D. Taylor, 2011. The assessment of fine sediment accumulation in rivers using macro-invertebrate community response. River Research and Applications 29: 17-55.

Faith, D. P., P. R. Minchin \& L. Belbin, 1987. Compositional dissimilarity as a robust measure of ecological distance. Vegetatio 69: 57-68.
Flores, L., A. Larrañaga, J. Díez \& A. Elosegi, 2011. Experimental wood addition in streams: effects on organic matter storage and breakdown. Freshwater Biology 56: 2156-2167.

Gerhard, M. \& M. Reich, 2000. Restoration of streams with large wood: effects of accumulated and built-in wood on channel morphology, habitat diversity and aquatic fauna. International Review of Hydrobiology 85: 123-137.

Golladay, S. \& R. Sinsabaugh, 1991. Biofilm development on leaf and wood surfaces in a boreal river. Freshwater Biology 25: 437-450.

Graf, W., 1997. A new record of the perlid stonefly Agnetina elegantula (Klapalek, 1905) in Europe. In Landolt, P. \& M. Sartori (eds), Ephemeroptera \& Plecoptera: BiologyEcology-Systematics. Mauron + Tinguely \& Lachat SA, Fribourg: 205-208.

Graf, W. \& T. Kovacs, 2002. The aquatic invertebrates of the Lafnitz-Raba river system in Austria and Hungary-a natural heritage of the Central European Potamocoen. International Association for Danube Research 34: 295-301.

Graf, W., U. Grasser \& J. Waringer, 2002a. Trichoptera-Teil III. In Moog, O. (ed.), Fauna Aquatica Austriaca, Lieferung 2002. Wasserwirtschaftskataster, Bundesministerium für Land- und Forstwirtschaft, Umwelt und Wasserwirtschaft, Wien.

Graf, W., U. Grasser \& A. Weinzierl, 2002b. Plecoptera-Teil III. In Moog, O. (ed.), Fauna Aquatica Austriaca, Lieferung 2002. Wasserwirtschaftskataster, Bundesministerium für Land- und Forstwirtschaft, Umwelt und Wasserwirtschaft, Wien.

Graf, W., P. Leitner, I. Hanetseder, L. D. Ittner, F. Dossi \& C. Hauer, 2016a. Ecological degradation of a meandering river by local channelization effects: a case study in an Austrian lowland river. Hydrobiologia 772: 145-160.

Graf, W., J. Murphy, J. Dahl, C. Zamora-Muñoz, M. J. LópezRodríguez \& A. Schmidt-Kloiber., A. 2016b. Dataset "Trichoptera". www.freshwaterecology.info-the taxa and autecology database for freshwater organisms, version 6.0 (accessed on 18.04.2016).

Gurnell, A., K. Gregory \& G. Petts, 1995. The role of coarse woody debris in forest aquatic habitats: implications for management. Aquatic Conservation 5: 143-166.

Gurnell, A., K. Tockner, P. Edwards \& G. Petts, 2005. Effects of deposited wood on biocomplexity of river corridors. Frontiers in Ecology and the Environment 3: 377-382.

Harmon, M. E., J. F. Franklin, F. J. Swanson, P. Sollins, S. V. Gregory, J. D. Lattin, N. H. Anderson, S. P. Cline, N. G. Aumen, J. R. Sedell, G. W. Lienkaemper, K. Cromack \& K. W. Cummins, 1986. Ecology of coarse woody debris in temperate ecosystems. Advances in Ecological Research 15: $133-302$.

Hering, D. \& M. Reich, 1997. Bedeutung von Totholz für Morphologie, Besiedlung und Renaturierung mitteleuropäischer Fließgewässer. Natur und Landschaft 72 : 383-390.

Hering, D., J. Kail, S. Eckert, M. Gerhard, E. Meyer, M. Mutz, M. Reuch \& I. Weiss, 2000. Coarse woody debris quantity and distribution in Central European Streams. International Review of Hydrobiology 85: 5-23. 
Hildrew, A. G. \& C. R. Townsend, 1976. The distribution of two predators and their prey in an iron rich stream. Journal of Animal Ecology 45: 41-57.

Hofer, N. \& J. S. Richardson, 2007. Comparisons of the colonisation by invertebrates of three species of wood, alder leaves, and plastic "leaves" in a temperate stream. International Review of Hydrobiology 92: 647-655.

Hoffmann, A. \& D. Hering, 2000. Wood-associated macroinvertebrate fauna in Central European Streams. International Review of Hydrobiology 85: 25-48.

Hohensinner, S., A. Drescher, O. Eckmüllner, G. Egger, S. Gierlinger, H. Hager, G. Haidvogl \& M. Jungwirth, 2016. Genug Holz für Stadt und Fluss? Wiens Holzressourcen in dynamischen Donau-Auen (Enough wood for city and river? Vienna's wood resources in dynamic Danube floodplains). Verlag Guthmann-Peterson, Vienna: 1-87.

Illies, J., 1978. Limnofauna Europaea. Gustav Fisher Verlag, New York: 1-532.

Jaccard, P., 1901. Étude comparative de la distribution florale dans une portion des Alpes et des Jura. Bulletin de la Société Vaudoise des Sciences Naturelles 37: 547-579.

Jäch M. A., F. Dietrich \& B. Raunig, 2005. Rote Liste der Zwergwasserkäfer (Hydraenidae) und Krallenkäfer (Elmidae) Österreichs (Insecta: Coleoptera). In Zulka. P. (ed.). Rote Listen gefährdeter Tiere Österreichs. Checklisten, Gefährdungsanalyse, Handlungsbedarf. Part 1: Säugetiere, Vögel, Heuschrecken, Wasserkäfer, Netzflügler, Schnabelfliegen, Tagfalter (Grüne Reihe des Lebensministeriums, Vol. 14/1). Bundesministerium für Land- und Forstwirtschaft, Umwelt und Wirtschaft, Wien: 211-284.

Kail, J., 2003. Influence of large woody debris on the morphology of six central European streams. Geomorphology 51: 207-223.

Kail, J., D. Hering, S. Muhar, M. Gerhard \& S. Preis, 2007. The use of large wood in stream restoration: experiences from 50 projects in Germany and Austria. Journal of Applied Ecology 44: 1145-1155.

Kaller, M. D. \& H. J. Hartmann, 2004. Evidence of a threshold level of fine sediment accumulation for altering benthic macroinvertebrate communities. Hydrobiologia 518: 95-104.

Kaufman, M. G. \& R. H. King, 1987. Colonization of wood substrates by the aquatic xylophage Xylotopus par (Diptera: Chironomidae) and a description of its life history. Canadian Journal of Zoology 65: 2280-2286.

Keller, E., A. MacDonald, T. Tally \& N. Merrit, 1995. Effects of large organic debris on channel morphology and sediment storage in selected tributaries of Redwood Creek, Northwestern California, U.S. Geological Survey Professional Paper 1454: 1-29.

Kruskal, J., 1964. Multidimensional scaling by optimizing goodness of fit to a nonnumeric hypothesis. Psychometrical 29: 1-27.

Laasonen, P., T. Muotka \& I. Kivijärvi, 1998. Recovery of macroinvertebrate communities from stream habitat restoration. Aquatic Conservation: Marine and Freshwater Ecosystems 8: 101-113.

Lance, G. N. \& W. T. Williams, 1967. A general theory of classificatory sorting strategies. I. Hierarchical systems. The Computer Journal 9: 60-64.
Levene, H., 1960. Robust tests for equality of variances. In Olkin, I. (ed.), Contributions to Probability and Statistics: Essays in Honor of Harold Hotelling. Stanford University Press, Palo Alto: 278-292.

Magoulick, D., 1998. Effect of wood hardness, condition, texture and substrate type on community structure of stream invertebrates. The American Midland Naturalist 139: 187-200.

Manners, R. B., M. W. Doyle \& M. J. Small, 2007. Structure and hydraulics of natural woody debris jams. Water Resources Research 43: 1-17.

Maser, C. \& J. R. Sedell, 1994. From the forest to the sea The ecology of wood in streams, rivers, estuaries, and oceans. St. Lucie Press, Delray Beach.

Miller, S. W., P. Budy \& J. C. Schmidt, 2010. Quantifying macroinvertebrate responses to in-stream habitat restoration: applications of meta-analysis to river restoration. Restoration Ecology 18: 8-19.

Milner, A. M. \& I. T. Gloyne-Phillips, 2005. The role of riparian vegetation and woody debris in the development of macroinvertebrate assemblages in streams. River Research and Applications 21: 403-420.

Mutz, M., 2003. Hydraulic effects of wood in streams and rivers. American Fisheries Society Symposium 37: 93-107.

O'Connor, N., 1992. Quantification of submerged wood in a lowland Australian stream system. Freshwater Biology 27: 387-395.

Ofenböck, T., O. Moog, A. Hartmann \& I. Stubauer, 2010. Leitfaden zur Erhebung der biologischen Qualitätselemente, Teil A2-Makrozoobenthos. Bundesministerium für Land- und Forstwirtschaft, Umwelt und Wasserwirtschaft, Wien: 1-224.

Pareira, C. R. D., N. Anderson \& T. Dudley, 1982. Gut content analysis of aquatic insects from wood substrates. Melanderia 39: 23-33.

Pilotto, F., A. Bertoncin, G. L. Harvey, G. Wharton \& M. T. Pusch, 2014. Diversification of stream invertebrate communities by large wood. Freshwater Biology 59: 2571-2583.

Pilotto, F., G. L. Harvey, G. Wharton \& M. T. Pusch, 2016. Simple large wood structures promote hydromorphological heterogeneity and benthic macroinvertebrate diversity in low-gradient Rivers. Aquatic Sciences 78: 755-766.

Robinson, E. \& R. Beschta, 1990. Characteristics of coarse woody debris for several coastal streams of Southeast Alaska, USA. Canadian Journal of Fisheries and Aquatic Sciences 47: 1684-1693.

Scherle, J., 1999. Entwicklung naturnaher Gewässerstrukturen, Grundlagen, Leitbilder, Planung. Mitteilungen des Institutes für Wasserwirtschaft und Kulturtechnik der Universität Karlsruhe (TH) 199.

Schmidt-Kloiber A. \& Hering D. (eds): www. freshwaterecology.info- the taxa and autecology database for freshwater organisms, version 6.0 (accessed on 18.04.2016)

Shields, F., N. Morin \& R. Kuhnle, 2001. Effect of Large Woody Debris Structures on Stream Hydraulics. Proceedings of the 2001 Wetlands Engineering and River Restoration Conference [CD-ROM], edited by D. F. Hayes, American Society of Civil Engineers, Reston, VA.

Sedell, J. R. \& F. Swanson 1984. Ecological characteristics of streams in old-growth forests of the Pacific Northwest. In: 
Meehan, W. R., T. R. Merrell Jr. \& T. A. Hanley (eds), Fish and wildlife relationships in old-growth forests: Proceedings of a symposium. American Institute of Fishery Research Biologists: 9-16.

Sinsabaugh, R. L., S. Golladay \& A. Linkins, 1991. Comparison of epilithic and epixylic biofilm development in a boreal river. Freshwater Biology 25: 179-187.

Smock, L., E. Gilinsky \& D. L. Stoneburner, 1985. Macroinvertebrate production in a Southeastern United States blackwater stream. Ecology 66: 1491-1503.

Smock, L., G. Metzler \& J. Gladden, 1989. Role of debris jams in the structure and function of low-gradient headwater streams. Ecology 70: 764-775.

Smock, L., J. Gladden, L. Riekenberg, L. Smith \& C. Black, 1992. Lotic macroinvertebrate production in three dimensions: channel surface, hyporheic, and floodplain environments. Ecology 73: 876-886.

Speaker, R., K. Moore \& S. Gregory, 1984. Analysis of the processes of retention of organic matter in stream ecosystems. Verhandlung der Internationale Vereinigung für Theoretische und Angewandte Limnologie 22: 110-116.

Strahler, A., 1957. Quantitative analysis of watershed geomorphology. Transactions of the American Geophysical Union 38: 913-920.
Sweeney, B. W., 1993. Effects of streamside vegetation on macroinvertebrate communities of White Clay Creek in Eastern North America. Proceedings of the Academy of Natural Sciences of Philadelphia 144: 291-340.

Tockner, K., U. Uehlinger \& C. T. Robinson, 2009. Rivers of Europe. Amsterdam: Academic Press. http://public.eblib. com/choice/publicfullrecord.aspx?p=421047.

Urbanek, B., M. Hinterhofer \& H. Kummer. 1999: Totholz in Fließgewässern-Literaturrecherche und Analyse ausgewählter Aspekte. Studie im Auftrag der Internationalen Regierungskommission Alpenrhein, Projektgruppe Gewässer- und Fischökologie: 1-64.

Vannote, R., G. Minshall, K. Cummins, J. Sedell \& C. Cushing, 1980. The River Continuum concept. Canadian Journal of Fisheries and Aquatic Sciences 37: 130-137.

Wallace, J. B. \& C. A. Benke, 1984. Quantification of wood habitat in subtropical coastal plain streams. Canadian Journal of Fish and Aquatic Science 41: 1643-1652.

Wohl, E. \& K. Jaeger, 2009. A conceptual model for the longitudinal distribution of wood in mountain streams. Earth Surface Processes and Landforms 34: 329-344.

Wood, P. \& P. Armitage, 1997. Sediment deposition in a small lowland stream-management implications. Regulated Rivers Research and Management 21: 203-217. 